\title{
Prorocka interpretacja exodusu. I. Amos, Ozeasz
}

\section{The Prophetic Interpretation of Exodus. Part I. Amos, Hosea}

Słowa klucze: exodus; Księga Amosa; Księga Ozeasz; naród wybrany; przymierze; historia zbawienia.

Keywords: exodus; Amos; Hosea; chosen people; covenant; salvific history.

Streszczenie. W księgach prorockich napotyka się różne spojrzenie na exodus, który otrzymuje różną artykulację teologiczną i egzystencjalną. Celem artykułu jest zbadanie, do jakich elementów toposu exodusu odwołują się prorocy i jakie miejsce przypisują mu w swoim przepowiadaniu. Pierwsza część artykułu dotyczy proroctw Amosa i Ozeasza. Obaj działali w VIII w. w Królestwie Północnym, prezentując odmienne ujęcie teologiczne exodusu. Ozeasz pogłębia idealizujące rozumienie exodusu w Izraelu jako fundamentu tożsamości narodu wybranego, natomiast Amos, pochodzący z Judy, dokonuje relatywizacji tego wydarzenia w perspektywie historii, uznając za podstawę tożsamości Izraela przymierze z Jahwe.

\begin{abstract}
There is a different view of the exodus in the prophetic books. The aim of the article is to verify the use of the exodus topos by the prophets, especially the significance of this event for their teaching. In the first part of the article the author examines the exodus motif in Amos and Hosea. Hosea develops the exodus theology existing the North Kingdom. Whereas for Hosea the exodus is the fundament of the identity of the chosen people, Amos distances himself from this idealizing lecture of exodus and announces the reversal of exodus as a punishment for Israel's infidelity.
\end{abstract}

Wyjście z Egiptu jest wydarzeniem najczęściej przywoływanym w Starym $\checkmark$ Testamencie. Stanowi centralny punkt wyznania wiary biblijnego Izraela (por. Pwt 26,5-9; Joz 24,1-13). Exodus leży u fundamentów tożsamości tego narodu, który wybrany przez Jahwe, staje się Jego ludem, On zaś objawia się jako ich Bóg. Wspominanie Wyjścia nie ma na celu tylko konserwowanie i podtrzymywanie pamięci o tym wydarzeniu. W tradycji biblijnej następuje 
przekształcenie exodusu w „siłę rodzącą, która jest zdolna do modelowania i interpretowania innych zdarzeń"1. W świetle exodusu Izraelici odczytują swoje doświadczenia z historii, przez co każde kolejne pokolenie może powiedzieć, że jest tym, które wyszło z Egiptu (por. traktat Pesahim 10,5). Tym samym Wyjście jest elementem strukturyzującym historię zbawienia, przekształcając ją $\mathrm{w}$ „teologiczny archetyp soteriologii biblijnej”2.

Wyjście jako przedmiot lektury typologicznej w Biblii pojawia się najczęściej w literaturze prorockiej ${ }^{3}$ i kojarzy się przede wszystkim $z$ wyroczniami pochodzącymi od anonimowego proroka nazywanego Deutero-Izajaszem, zapowiadającego nowy exodus. Okazuje się jednak, że tego rodzaju interpretacja Wyjścia jest jedną z wielu podejmowanych przez proroków. Ich lektura exodusu układa się w swoisty wielogłos, w którym ta centralna prawda wiary biblijnego Izraela otrzymuje różną artykulację teologiczną i egzystencjalną. Nierzadko ma się do czynienia z konkurującym wręcz ze sobą prorockimi teologiami exodusu. Czy są to jednak głosy wykluczające się? Co wpływa na odmienne spojrzenie wśród proroków na wydarzenie Wyjścia? Jakie miejsce temu wydarzeniu wyznaczają oni w historii zbawienia? Do jakich elementów toposu exodusu i dlaczego odwołują się w swoim nauczaniu?

Szukanie odpowiedzi na tak postawiony problem wymaga odwołania się do przepowiadania kilku proroków, by móc uchwycić przyczyny tej swoistej polifoniczności rozumienia exodusu w korpusie prorockim. W poniższym artykule analiza obejmie przepowiadanie najpierw Amosa i Ozeasza, którzy jako pierwsi wśród proroków podjęli się interpretacji exodusu. Obaj działali w Królestwie Północnym w okresie poprzedzającym upadek Samarii w 722 r. Mając na uwadze fakt, że Amos pochodził z Judy, będzie możliwe zweryfikowanie, jak wyglądała pierwotna interpretacja exodusu przez proroków wywodzących się z różnych królestw podzielonego Izraela. Przedmiotem analizy w następnym artykule będą wyrocznie Ezechiela i Deutero-Izajasza, wygłoszone półtora wieku później w kontekście wygnania babilońskiego. Ich zapowiedzi nowego exodusu różnią się między sobą, przez co konieczne jest pytanie o źródło i sens ich odmiennego rozumienia nowego Wyjścia.

1 L. Alonso Schökel, Salvezza e liberazione, s. 27.

2 Ibidem.

3 Zjawisko typologicznego odczytywania exodusu przez proroków jako przykład lektury wewnątrzbiblijnej jest szerzej omówione w: M. Fishbane, Biblical Interpretation, s. $358-368$. 


\section{Amos: relatywizacja znaczenia exodusu}

Aktywność proroka Amosa datuje się na połowę VIII w. przed Chr. Pochodzi z Tekoa leżącego niedaleko Betlejem, a więc z terenu Królestwa Południowego, działa tymczasem na obszarze Królestwa Północnego, kierując swoje wyrocznie do mieszkańców Izraela. W ten sposób w jego przepowiadaniu dochodzi do swoistego zderzenia się dwóch różnych tradycji: Izraela i Judy. Zauważa się to również w odniesieniu do rozumienia exodusu.

Wydarzenie Wyjście jest wzmiankowane bezpośrednio w Księdze Amosa w 2,9-10; 3,1-2 i 9,7. Nawiązanie do plag egipskich wydaje się być czynione w Am 4,10 i 5,17. Natomiast aluzji do wędrówki przez pustynię można doszukiwać się w Am 5,25. Zanim przystąpi się do bliższej analizy wymienionych tekstów, należy ustosunkować się do pojawiającej się w części komentarzy (przede wszystkim Hansa W. Wolffa) opinii odmawiającej Amosowego autorstwa wierszy 2,9-10 i 3,1-2 na rzecz redakcji deuteronomicznej/deuteronomistycznej.

W przypadku urywka 2,9-10 zwraca się uwagę przede wszystkim na odwrócenie w nim chronologii zdarzeń (w. 9 [zniszczenie Amorytów w związku z zajęciem ziemi] powinien poprzedzać w. 10 [wyjście z Egiptu, wędrówka przez pustynię]) oraz na słownictwo dtr w w. 10 (użycie czas. ' $\bar{a} l \bar{a}^{h}$ w $\mathrm{Hi}$ w zwrocie „wyprowadzić z ziemi egipskiej”, „czterdzieści lat” jako określenie czasu wędrówki przez pustynię) $)^{4}$. Powyższe zastrzeżenia nie mają jednak wystarczającej siły dowodowej, by odrzucić Amosowe pochodzenie tego tekstu. Gdyby rzeczywiście obecny kształt urywka 2,9-10 był wynikiem redakcji, to tym bardziej dziwiłoby odwrócenie przez redaktora porządku chronologicznego zdarzeń opisanych w tym tekście. Twierdzenie o słownictwie deuteronomicznym w w. 10 jest dyskusyjne $\mathrm{z}$ tego powodu, że tradycja deuteronomiczna nie stosuje czasownik $\complement_{\bar{a}} \bar{a}^{h}$ w Hi w zwrocie określającym Wyjście z Egiptu, lecz sięga po czasownik yāṣa $\bar{a}^{h} \mathrm{w} H i^{5}$. Na przeddeuteronomiczne pochodzenie syntagmy ${ }^{\complement} \bar{a} l \bar{a}^{h}$ w Hi $+m \bar{e}^{-}$eres miṣrayim wskazuje jej wystąpienie w Mi 6,4, co dowodzi, iż w VIII w. przed Chr. było to konwencjonalne określenie exodu$s u^{6}$. Przemawia za tym również fakt, że w Księdze Amosa czasownik ālăh w Hi w kontekście Wyjścia pojawia się jeszcze w 3,1 i 9,7. Twierdzenie, że motyw

4 Por. W.H. Schmidt, Die deuteronomistische Redaktion AW, s. 178-183; H.W. Wolff, Joel and Amos, s. 169-170; J. Jeremias, Der Prophet Amos TD, s. 25.

5 Jedyne miejsce, w którym tradycja deuteronomiczna wykorzystuje w tym zwrocie czasownik ${ }^{\complement} \bar{a} \bar{a}^{h}$ w Hi, to Pwt 20,1, jednakże wzmianka o Wyjściu jest tam czyniona w kontekście zupełnie niezwiązanym z exodusem.

6 Por. J.L. Mays, Amos, s. 51. 
czterdziestu lat spędzonych na pustyni nie był znany przed tradycja deuteronomiczną, jest również problematyczne, gdyż pojawia się on jeszcze w Am 5,25, który wolny jest od śladów ingerencji ze strony redaktorów $\mathrm{D} / \mathrm{dtr}{ }^{7}$. W przypadku typowego dla tradycji D/dtr zwrotu lārešet ’et-’oreṣ („wziąć w posiadanie ziemię"; np. Pwt 2,31; 9,4.5; 11,3; Joz 1,11; 18,3) nie można jednak twierdzić, że jest on innowacją semantyczną dopiero tradycji deuteronomicznej, gdyż ta mogła zaadaptować wcześniejsze sformułowania, których używał już Amos. Poza tym nieuzasadniona jest opinia, że elementy tradycji deuteronomicznej nie istniały w jakiejś postaci przed VII w., przez co nie mogły być znane i używane przez Amosa w VIII w. ${ }^{8}$.

Nie można zaprzeczyć, że w obecnym kształcie tekst Am 3,1-2 jest syntaktycznie przeładowany, co wynika przede wszystkim ze zdublowania w w. 1 adresata: przedstawiony w w. 1a jako „do was, synowie Izraela” zostaje on w w. lb dookreślony jako „do całego pokolenia [Kol-hammišpāhāa ${ }^{2}$, który wyprowadziłem z ziemi egipskiej”9. To apozycyjne określenie można tłumaczyć na różne sposoby, niekoniecznie jako deuteronomistyczne rozszerzenie redakcyjne ${ }^{10}$. Zdublowanie określenia audytorium może być zabiegiem retorycznym, dzięki któremu prorok cytuje słowa swoich słuchaczy przekonanych o byciu wyprowadzonym przez Boga $\mathrm{z}$ niewoli egipskiej ${ }^{11}$. Intencją proroka nie jest tylko polemika z popularnym wśród mieszkańców Izraela przekonaniem o swoim szczególnym statusie wobec Jahwe dzięki exodusowi, ale też podkreślenie, że w gronie uczestników tamtego wydarzenia byli również mieszkańców Judy ${ }^{12}$.

Patrząc całościowo na Amosowe odniesienia do exodusu, należy stwierdzić, że zna on tradycję o wyprowadzeniu Izraelitów przez Jahwe z Egiptu (por. he ělêtî 'etkem mē̉ereș miṣrāyim w 2,10; 3,1; 9,7), dostępna jest mu informacja o plagach (w 4,10 wspomina zarazę [deber], którą Jahwe zesłał na Egipt [por. Wj 9,3-7.15], a w 5,17 zapowiada „przejście” Jahwe pośrodku Izraela na podobieństwo przejścia w Egipcie, które przyniosło śmierć pierworodnym

7 Por. S.M. Paul, Amos, s. 89. Motyw czterdziestu lat wędrówki przez pustynię znany jest także innym tradycjom niż deuteronomiczna (por. Wj 16,35; Lb 14,33-34; 32,13; Joz 5,6; Ps 95,10).

8 Por. Y. Hoffman, A North Israelite, s. 179; F.I. Andersen, D.N. Freedman, Amos, s. $328-329$.

9 Inne elementy syntaktycznie dyskusyjne to: brak korespondencji między Jahwe mówiącym jako podmiot w $1 \mathrm{sg} \mathrm{w}$ w. 2 (yāda ${ }^{\top} t \hat{1}$ ), zaś w $3 \mathrm{sg} \mathrm{w}$ w. 1 ('ăšer dibber yhwh); lē̉mōr na końcu w. 1 jako wprowadzenie słów Jahwe po wcześniejszym wezwaniu do słuchania słów Jahwe.

\footnotetext{
10 Za taką redakcją optuje H.W. Wolff, Joel and Amos, s. 175.

11 Por. Y. Hoffman, A North Israelite, s. 180.

12 Por. W. Rudolph, Joel - Amos - Obadja - Jona, s. 100.
} 
Egipcjan [por. zwrot cābar b bo w Am 5,17 i Wj 12,12.23]); mówi o czterdziestu latach wędrówki przez pustynię (por. 2,10; 5,25); wreszcie przywołuje dar ziemi, którą posiedli Izraelici po pokonaniu pierwotnych mieszkańców Kanaanu (por. 2,9-10). Amos daleki jest jednak od przypisywania wydarzeniu Wyjścia kluczowej roli w historii Izraela ani też nie postrzega go jako doświadczenia mającego być podstawą uprzywilejowanej, jedynej w swoim rodzaju pozycji Izraela wobec Jahwe.

Struktura urywka 2,9-10, w którym reasumuje się epizody z okresu Wyjścia, przez inkluzyjną pozycję terminu Amoryci (ww.9a.10b) eksponuje na pierwszym miejscu dar ziemi, natomiast sam exodus traktuje jako jedno $\mathrm{z}$ wielu wydarzeń $\mathrm{z}$ historii zbawienia. W perspektywie historii światowej exodus Izraelitów z Egiptu nie różni się od podobnych interwencji Jahwe wobec innych narodów. Wskazuje na to podwójne pytanie sformułowane przez Jahwe w 9,7: „Czy nie jak Kuszyci jesteście wy dla mnie, synowie Izraela? Czy nie wyprowadziłem Izraela z ziemi egipskiej, Filistynów z Kaftor, a Aramejczyków z Kir?” Kuszyci będący mieszkańcami Nubii (Etiopii) pozostawali dla Izraelitów ludem zamieszkującym bardzo odległe ziemie (por. Iz 18,1-2). Tymczasem Jahwe jest tak samo zainteresowany ich historią jak historią Izraela. Co więcej, przedmiotem zainteresowania Jahwe są również ludy leżące blisko Izraela, a pozostające jego nieprzyjaciółmi: Filistyni oraz Aramejczycy. W kontekście wrogości tych ludów wobec Izraelitów jeszcze mocniej wybrzmiewają słowa proroka, w których Bóg mówi, iż wyprowadzenie Izraelitów z Egiptu nie było czymś wyjątkowym w historii świata, bo w podobny sposób Jahwe wyprowadził Filistynów z Kaftor, a Aramejczyków z Kir. Nie sposób zatem wybrania Izraela opierać na wydarzeniu exodusu, gdyż podobne doświadczenia innych narodów dowodzą, że w Jahwe „nie ma preferencji etnicznych ani geograficznych, ani też politycznych czy historycznych" ${ }^{\prime 3}$. Mimo że nie można podać całkowicie pewnej lokalizacji wymienionych w 9,7 nazw geograficznych ${ }^{14}$, to wzmianka o wyprowadzeniu Aramejczyków z Kir, czytana w łączności z wcześniejszą zapowiedzią w 1,5 uprowadzenia Aramejczyków z powrotem do Kir (por. 2 Krl 16,9), dowodzi, że Jahwe jest absolutnym Panem historii narodów. Gdy okrucieństwo Aramu domaga się interwencji Jahwe, Ten, mimo że wcześniej wyprowadził Aram z Kir, teraz z powrotem skazuje go na uprowadzenie do Kir.

13 S.M. Paul, Amos, s. 282. Yair Hoffman mówi w kontekście Am 9,7 o exodusie jako „Bożej rutynie” w przesiedlaniu narodów z jednego miejsca na inne (A North Israelite, s. 181).

14 Najprawdopodobniej Kir należy łączyć z Elamem (por. Iz 22,6), natomiast Kaftor z Kretą (por. F.I. Andersen - D.N. Freedman, Amos, s. 257, 869; J. Jeremias, Der Prophet Amos, s. 131). 
W tym kontekście stają się zrozumiałe słowa wyroczni 3,1-2. Adresaci Amosa mienią się być „całym pokoleniem [hammišpāḥa $\left.\bar{a}^{h}\right]$, które Jahwe wyprowadził z ziemi egipskiej” (w. 1). Jednakże to doświadczenie wyjścia nie czyni Izraelitów kimś uprzywilejowanym w stosunku do innych „pokoleń [mišpoḥôt] ziemi” (w. 2), jako że pozostają oni jednym z wielu „pokoleń” żyjących w świecie. W ten sposób Amos dokonuje relatywizacji motywu exodusu dla tożsamości i historii Izraela. Podstawą wyróżnienia Izraela spośród innych narodów ziemi jest wybór, jakiego dokonał Jahwe w stosunku do nich. Na określenie tego wyboru Amos używa czasownika yāḍac, a nie bāḥar, jak czyni to późniejsza tradycja deuteronomiczna (por. Am 3,2 z Pwt 10,15). Czasownik yād $a^{c}$ wyraża intymność więzi, jaką związał się Jahwe ze swoim ludem w przymierzu. To „poznanie” właściwe jest relacji małżeńskiej, która w tekstach prorockich wielokrotnie jest wykorzystywana metaforycznie jako obraz przymierza Jahwe i Izraela (np. u Jr, Ez, Oz). W tej perspektywie „poznanie” przez Jahwe oznacza wybranie, które jest wyrazem umiłowania i zatroszczenia się o swój lud. To właśnie Boże umiłowanie wyróżnia Izrael spośród innych ludów ziemi.

Dla Izraelitów wybranie przez Jahwe było postrzegane jako źródło tylko przywilejów i beneficjów. Co więcej, stanowiło gwarancję niekaralności ze strony Jahwe, będącego związanym przymierzem. Tę postawę zadufania, pychy i poczucia bezkarności demaskują słowa samych Izraelitów, które Amos przytacza w swoich wyroczniach. Są przekonani, że „Jahwe, Bóg Zastępów jest z nimi” $(5,14)$. Na tej podstawie twierdzą, że „nie zbliży się ani ich nie spotka nieszczęście" $(9,10)$. Dobrobyt materialny i korzystna sytuacja międzynarodowa w połowie VIII w. ma według nich dowodzić błogosławieństwa ze strony Jahwe, a tym samym potwierdzać, że we właściwy sposób - przede wszystkim przez rozbudowany kult - odpowiadają na wymagania, jakie stawia im Bóg w przymierzu. Prorok kwestionuje taką postawę, odwołując się raz jeszcze do exodusu, a dokładniej do doświadczenia wędrówki przez pustynię. Na pytanie postawione w 5,25: „Czy składaliście Mi ofiary krwawe i ofiary pokarmowe na pustyni przez czterdzieści lat, domu Izraela?”, jedyna poprawna odpowiedź brzmi: nie. Łaskawość ze strony Jahwe doświadczana na pustyni nie była wynikiem jakiś zasług Izraelitów czy ich szczególnych przymiotów, ani też nie była odpowiedzią na jakieś akty kultu ofiarniczego, które na pustyni były problematyczne z powodu braku materii ofiarniczej $^{15}$. Pozostawała wolną decyzją Boga, który ich umiłował i oczekiwał tylko zaufania i posłuszeństwa swojemu słowu. Ten wymóg jest aktualny również w połowie VIII w. Słowo Boże, któremu Izraelici mają być posłuszni,

15 Por. S.M. Paul, Amos, s. 192. 
dotyczy nie przepisów regulujących kult i ofiary (por. 4,21-23), lecz prawa i sprawiedliwości w życiu społecznym (por. 4,24). Stąd wezwanie do szukania Jahwe nie w świątyni (por. 5,5), lecz w bramie miasta jako miejscu, w którym ma być realizowany Boży ideał sprawiedliwości w życiu wspólnoty (por. 5,14-15). Wobec braku odpowiedzi ze strony narodu wybranego na te postulaty etyczno-moralne Bóg zapowiada przez proroka odwróceniu exodusu. Zapowiedź kary w tym kontekście jest paradoksalna: nie pojawia się groźba uprowadzenia na powrót w niewolę, ale zwiastowana jest kara w postaci nieszczęść korespondujących z plagami egipskimi: zarazy, która spadnie na lud ,jak w Egipcie” $(4,10)$, oraz śmierci pierworodnych na skutek „przejścia” Pana w noc paschalną $(5,17)$.

Podsumowując analizę Amosowego rozumienia exodusu, należy podkreślić, że traktuje on go jako jedno $\mathrm{z}$ wielu wydarzeń $\mathrm{z}$ historii zbawienia. Podstawę tożsamości Izraela jako ludu Jahwe stanowi Boże wybranie tego narodu. Doświadczenie exodusu nie jest wyłącznym przywilejem Izraela, gdyż Jahwe prowadzi historię także innych narodów ziemi. Uprzywilejowana pozycja Izraela jest tylko i wyłącznie rezultatem łaskawości Jahwe, a nie wynika $\mathrm{z}$ jakiś osobistych przymiotów czy zasług Izraela. Jako lud przymierza Izraelici są zobowiązani do realizowania w swoim życiu społecznym Bożego ideału sprawiedliwości. Odejście od niego skutkować będzie karą nawiązującą w swojej formie do kar, które dotknęły Egipcjan podczas Wyjścia Izraelitów. Ta krytyczna wizja exodusu pochodzi od proroka judzkiego i przeciwstawia się jednostronnemu ujęciu tego wydarzenia przez mieszkańców Izraela, którzy właśnie na exodusie chcieli budować swoją uprzywilejowaną pozycję wobec Jahwe w świecie. Amos tymczasem dokonuje krytycznej rewizji ich rozumienia exodusu.

\section{Ozeasza: idealizacja exodusu}

Prorok Ozeasz pozostaje współczesny Amosowi, jednakże jego aktywność trwa aż do upadku Samarii w 722 r. przed Chr. Jest mieszkańcem Królestwa Północnego, co znajduje swoje odzwierciedlenie w języku jego wyroczni, w którym identyfikuje się elementy dialektu północnego ${ }^{16}$, znajomości realiów życia społecznego, religijnego i politycznego w Samarii, ale również w teologii, która pozostaje wyraźnie odmienna od tej w Judzie. Taki wniosek można wysnuć m.in. na kanwie lektury tekstów, w których Ozeasz podejmuje motyw exodusu.

16 Por. analizę języka Księgi Ozeasza pod kątem występowania w nim dialektu północnego w: A.A. Macintosh, A Critical and Exegetical Commentary on Hosea, s. liv-lvii. 
Temat exodusu jest przywoływany najpierw przez bezpośrednie odniesienia do tradycji o wybawieniu Izraela z Egiptu. Dwukrotnie - w Oz 12,10; 13,4 pojawia się formuł autoprezentacji Boga: „Ja jestem Jahwe, twój Bóg, od ${ }^{17}$

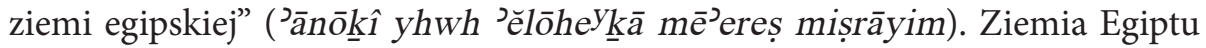
jest miejscem, z którego Jahwe wyprowadził Izrael (2,17: yôm ‘ălōtāh mểereș-mișrāyim), z którego wezwał swojego syna (11,1: mimmiṣrayim qārā̃̂t libnnî). To w Egipcie Izrael przeżywał swoją młodość, na co wskazuje określenie tamtego czasu w 2,17 jako „dni jego młodości” (mê no'ûre $\left.{ }^{y} h a \overline{)}\right)$, korespondujące ze zdaniem podrzędnym otwierającym narrację w 11,1: „kiedy Izrael był dzieckiem” (kî na`ar yiśrāēè $)^{18}$. Wtedy też Izrael, „umiłowany” przez Jahwe (11,1: kî na ‘ar yiśrā’ēel wā̄ōhăbēhû), „odpowiedział"19 ochoczo na ten akt mi-

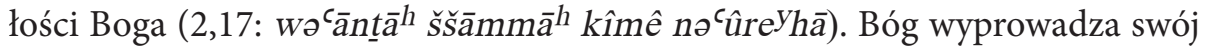
lud z Egiptu za pośrednictwem nienazwanego z imienia proroka ${ }^{20}$ : „przez proroka wyprowadził (hecěla $\left.\bar{a}^{h}\right)$ Jahwe Izrael z Egiptu i przez proroka był chroniony (nišmar)" $(12,14)$.

Wyjście z Egiptu pozostaje ściśle powiązane z wędrówką przez pustynię. Ten związek zauważa się w 2,16-17; 12,10 i 13,4-5. W dwóch pierwszych tekstach zostają zestawione paralelnie w odmiennych perspektywach czasowych dwa wydarzenia: przeszłe wyjście z ziemi egipskiej $(2,17 ; 12,10 a)$ i przyszła

17 Przyimek min użyty w znaczeniu czasowym wskazuje na terminus a quo (por. P. Joüon, T. Muraoka, A Grammar of Biblical Hebrew, $\$ 133 \mathrm{e}$ ). Część komentatorów dopuszcza znaczenie lokalowe przyimka przy założeniu, że formuła obecna w Oz 12,10 i 13,4 jest skróconą wersją tej pełnej, znanej np. z Wj 20,2: „Ja jestem Yahwe, twój Bóg, który cię wyprowadził z ziemi egipskiej" (por. F.I. Andersen, D.N. Freedman, Hosea, s. 617).

18 Użycie terminu na`ar w Oz 11,1 nie pozwala na doprecyzowanie, o jaki czas młodości Izraela chodzi. Termin ten może odnosić się zarówno do niemowlęcia (por. Wj 6,2), jak i do dziecka odstawionego już od piersi (por. Rdz 21,12), ale też do młodzieńca wchodzącego w obowiązki właściwe ludziom dorosłym (tak nazywa siebie Salomon rozpoczynający swoje rządy [por. $1 \mathrm{Krl} \mathrm{3,7]} \mathrm{czy} \mathrm{Jeremiasz} \mathrm{w} \mathrm{momencie} \mathrm{swego} \mathrm{powołania} \mathrm{na} \mathrm{proroka} \mathrm{[por.}$ Jr 1,6]).

19 Hans W. Wolff zauważa, że przysłówek šāmma $\bar{a}^{h}$ następujący po czasowniku ‘̄āna $\bar{a}^{h}$, tłumaczony jako „odpowiadać”, syntaktycznie zakłada czasownik ruchu: „odpowie i pójdzie za”, czyli „odpowie ochoczo” (Hosea, s. 43).

20 Większość komentatorów identyfikuje wspomnianego w tym wierszu dwukrotnie proroka z osobą Mojżesza (np. H.W. Wolff, Hosea, s. 216; M.A. Sweeney, The Twelve Prophets, I, s. 128). Są jednak propozycje, by pierwszego identyfikować z Mojżeszem, zaś drugiego z Samuelem lub Eliaszem (por. F.I. Andersen, D.N. Freedman, Hosea, 621). Jest wreszcie sugestia, by w tym bezimiennym proroku widzieć odniesienie nie do Mojżesza, lecz do urzędu prorockiego jako takiego (por. E.K. Holt, Prophesying in the Past, s. 48; J.A. Dearman, The Book of Hosea, s. 37). 
wędrówka przez pustynię $\left(2,16 ; 12,10 b^{21}\right)$. W kontekście historycznego exodusu rozumianego jako wybór Izraela przez Jahwe te dwa zdarzenia: wyjścia i wędrówki, są tożsame, co potwierdza tekst 13,4-5: w. 4 przynosi formułę autoprezentacji Jahwe jako ich Boga od ziemi egipskiej, natomiast w. 5 zawiera wyznanie Jahwe, że „poznał ich na pustyni, w wyschniętej ziemi”. Mimo że na płaszczyźnie czasowo-przestrzennej wyjście z Egiptu jest uprzednie wobec wędrówki przez pustynię, to na płaszczyźnie teologicznej nakładają się one na siebie jako jedno wydarzenie wybrania Izraela przez Boga. W rezultacie, kiedy Ozeasz w 9,10 mówi o „znalezieniu” Izraela „jak winne grono na pustyni”, ma na myśli również wyjście z Egiptu.

Tradycja o Wyjściu z Egiptu jest wcześniejsza od Ozeasza, na co wskazuje dwukrotne użycie przez niego tej samej formuły autoprezentacji ${ }^{22}$ : „Ja jestem Jahwe, twój Bóg, od ziemi egipskiej" $(12,10 ; 13,4)$. Podstawowa forma tej formuły: „Ja jestem Jahwe”, zostaje rozbudowana o dwa elementy: pierwszy - „twój Bóg” - przywołuje jeden z elementów formuły wzajemnej przynależności opisującej relację przymierza, drugi natomiast - „od ziemi egipskiej” - wskazuje na czas zawiązania tej relacji. Hans W. Wolff uznaje przywołaną przez Ozeasza formułę za „część pierwotnego creda Izraela”23. Kształtuje się ona w środowisku kultycznym, z którego zostaje przejęta przez proroków (przede wszystkim Ezechiela i Deutero-Izajasza) ${ }^{24}$. W klucie służyła ona za rodzaj historycznej weryfikacji prawdy o Jahwe jako zbawcy Izraela (por. Oz 13,4b). Sposób użycia tej formuły przez Ozeasza dowodzi, że funkcjonowała ona w połowie VIII w. jako niezależna wypowiedź w ramach liturgii (najprawdopodobniej w Betel) ${ }^{25}$. Zauważa się, że formuła zastosowana przez Ozeasza przypomina prolog historyczny do Dekalogu (Wj 20,2; Pwt 5,6). Nie wydaje się jednak, że ten tekst jest źródłem, z którego korzysta prorok (kopiując lub czynią interpolację) ${ }^{26}$. Po pierwsze, w prologu do Dekalogu wyprowadzenie Izraela z Egiptu przez Jahwe oddane jest czasownikiem yāṣă $\bar{a}^{\jmath} \mathrm{H} i$, podczas gdy Ozeasz używa w tym

21 Wg Oz 12,10b Bóg sprawi, że Izrael „jeszcze zamieszka w namiotach jak za dni spotkania (kîmê mô $\left.\hat{e}^{\complement} \underline{d}\right)$ ". Motyw mieszkania w namiotach wiąże się z wybawieniem z Egiptu i wędrówką przez pustynię.

22 Analizę tej formuły przeprowadza W. Zimmerli, Io sono Jahvé, Rivalazione di Dio, s. 19-44 (analiza Oz 12,10; 13,4 na s. $31-32$ ).

23 H.W. Wolff, Hosea, s. 197.

24 Por. W. Zimmerli, Un genere profetico, s. 114.

25 Por. F.I. Andersen, D.N. Freedman, Hosea, s. 617; E.K. Holt, Prophesy in the Past, s. $61-62$.

26 Taką zależność Oz 12,10; 13,4 od Dekalogu sugerują m.in.: W. Rudolph, Hosea, s. 234; A.A. Macintosh, A Critical and Exegetical Commentary on Hosea, s. 499; E. Ben Zvi, Hosea TL, s. 252; J.A. Dearman, The Book of Hosea, s. 310. 
kontekście czasownika ${ }^{\complement} \bar{a} l \bar{a}{ }^{h} \mathrm{w} H i$. Po drugie, dyskutowana formuła pojawia się w proroctwie Ozeasza poza „dekalogowym” kontekstem, łącząc się z ideą wędrówki przez pustynię $e^{27}$. Prorok podejmuje zatem istniejącą już tradycję o exodusie, by poddać ją teologicznemu pogłębieniu.

Wspomniana już formuła autoprezentacji Jahwe z Oz 12,10; 13,4 wskazuje na relację przymierza, jaka wiąże Jahwe z Izraelem. Fundamentem tej relacji nie jest przymierze synajskie, lecz wyjście z ziemi egipskiej. Ozeasz odczytuje exodus jako czyn miłości ze strony Jahwe względem swego ludu, opisując go w kluczu różnych metafor. W 11,1 Bóg mówi o „umiłowaniu Izraela, gdy jeszcze był dzieckiem”, o „wezwaniu swego syna z Egiptu”. Kluczem interpretacyjnym do wybrania Izraela w Egipcie jest miłość Boga. Pierwszy epizod z życia młodego Izraela, uznany przez proroka za godny wzmiankowania, to umiłowanie go przez Boga. Nazwanie Izraela „swoim synem” wskazuje na osobiste, pełne uczucia zaangażowanie się Jahwe w historię swego ludu (por. Wj 4,22-23). Emocje, które towarzyszyły Bogu w momencie exodusu, można odczytać w metaforze roślinnej w $\mathrm{Oz} 9,10$. Izrael zostaje przyrównany do „winnego grona na pustyni” i „pierwszych owoców figowca”, które „znalazł” Bóg. Gdy wędrowiec napotyka niespodziewanie na pustyni (pewnie w jakieś zasłoniętej dolinie lub oazie) winogrona, jest mile zaskoczony tym znaleziskiem, wzbudza ono w nim radość i pragnienie spożycia. Podobne reakcje towarzyszą komuś, kto dostrzeże na figowcu pierwsze w sezonie figi (por. Iz 28,4; Mi 7,1) ${ }^{28}$. Jahwe znajduje upodobanie w Izraelu, dostrzega jego wartość, doświadcza radości w spotkaniu z nim, nazywa go swoim synem. Nie jest to tylko kwestia formalnej relacji ojciec-syn, ale pełne miłości zatroskanie się o swego syna, gdy ten znajduje się w niesprzyjających czy wręcz wrogich mu okolicznościach życia. W tym kierunku można interpretować wzmiankę o „poznaniu” Izraela na pustyni przez Boga, który „pasie ich” i „nasyca” $(13,5)$, dając się w ten sposób poznać jako „ich Bóg”. Ta miłość Boga do Izraela jest pełna emocji, pasji i namiętności właściwej dwojgu zakochanych w sobie. Zapowiedzi przyszłego wyprowadzenia na pustynię w 2,16 towarzyszy język zalotów: Bóg chce ,ją przynęcić2 ${ }^{29}$ [...] i przemówić do jej serca”. To perspektywiczne spojrzenie na relację Jahwe z Izraelem, opisywaną w rozdz. 2 księgi za pomocą metafory małżeńskiej, pozwala rozumieć historyczny exodus jako czas zalotów i zabiegów ze strony Jahwe względem swojej oblubienicy-Izraela (por. Jr 2,2; 3,4).

\footnotetext{
27 Por. E.K. Holt, Prophesy in the Past, s. 62.

28 Por. M.L. Corrêa Lima, Os 9,10-17, s. 159-160.

29 Czasownik pātāh w Pi można tłumaczyć jako „uwodzić, wabić, czynić zaloty, zabiegać o względy" (por. Sdz 14,15; 16,5; Hi 31,9.27).
} 
W ujęciu Ozeasz historia exodusu jest wolna od jakichkolwiek epizodów buntu czy niewierności Izraela względem Jahwe. Pierwsze odstępstwo ma miejsce dopiero w Baal Peor, w którym „oddali się hańbie i stali się obrzydliwi jak to, co kochali” $(9,10)$. Następuje ono zatem dopiero w spotkaniu z kananejskimi kultami płodności na ziemi Moabu, tuż przed wkroczeniem do Ziemi Obiecanej (por. Lb 25,1-11; Pwt 4,3-4). To wiarołomne zachowanie Izraela kontrastuje z jego postawą „,w dniu, w którym wychodził z ziemi egipskiej, w dniach swej młodości” (Oz 2,17). Nakładając na siebie przyszłe wyprowadzenie na pustynię z przeszłym exodusem, prorok kreśli obraz idealnej relacji miłości między Jahwe i Izraelem: Bóg „mówi do serca” swojej oblubienicy $(2,16)$, ta zaś mu "odpowiada" i za Nim podąża $(2,17)^{30}$. Czasownik ‘ānăh powróci pięciokrotnie w w 2,21-22 dla ukazania odpowiedzi, jakiej udzielają sobie wzajemnie różne elementy stworzenia $\mathrm{w}$ procesie błogosławieństwa zainicjowanym przez Boga w nowym przymierzu. W tym kontekście odpowiedź Izraela w exodusie nie pozostawała, zdaniem Ozeasza, na poziomie formalnego posłuszeństwa, lecz była odpowiedzią serca na zaproszenie ze strony miłującego Boga. Tę relację miłości cechowała bliskość, intymność, czułość i wyłączność właściwe małżonkom ${ }^{31}$. Wszystko zmienia się wraz z wejście do Kanaanu, gdzie pod wpływem ludności tubylczej Izrael podąża za „swoimi kochankami, zapominając o” Jahwe $(2,15)$.

Zostało już wspomniane, że Ozeasz, prezentując wydarzenie Wyjścia, nie sięga po czasownik yāṣă ${ }^{\supset} \mathrm{w} \mathrm{Hi}$, jak ma to miejsce w formule otwierającej Deka$\log$ akcentującej fakt wyzwolenia z niewoli, lecz wykorzystuje czasownik $\varsigma_{\bar{a}} l \bar{a}{ }^{h}$ w $\mathrm{Hi}^{32}$. Zawiera on w sobie ideę wstępowania, która odpowiada geograficznym realiom wędrówki z równinnego terenu Egiptu w kierunku górzystej ziemi Kanaanu ${ }^{33}$. Tym samym czasownik czasownik ${ }^{\complement} \bar{l} l \bar{a}{ }^{h}$ wskazuje na cel exodusu, którym jest wejście do ziemi obiecanej przez Jahwe. Taki sposób rozumienia exodusu znajduje potwierdzenie w tekście 2,16-17, w którym schodzi się horyzont przeszłego i przyszłego exodusu. Po zapowiedzi wyjścia na pustynię i mówienia do serca Izraela-oblubienicy $(2,16)$ nie pojawia się słowo odpowiedzi ze strony Izraela, lecz następuje Boża zapowiedź przywrócenia mu winnic, symbolizujących całość ziemi uprawnej Palestyny ${ }^{34}$, do której bramą od strony Jordanu w centralnej części kraju będzie Dolina Akor. Żyzność i bogactwo tej ziemi jest

30 Jeremiasz tę myśl Ozeasza podda jeszcze dalej idealizacji, opisując postawę Izraela w trakcie Wyjście terminami „wierności” (hesed $)$ ), „miłości” ( 'ahăb $\left.\bar{a}^{h}\right)$ i „podążania za” Jahwe (hālak ’ahar), por. Jr 2,2.

31 Por. J.A. Dearman, The Book of Hosea, s. 123.

32 Por. M. Weinfeld, Deuteronomy 1-11, s. 287.

33 Por. L. Alonso Schökel, Salvezza e liberazione, s. 52.

34 Por. H.W. Wolff, Hosea, s. 42. 
opisane w 2,10-11.14. Ofiarowując Izraelowi ziemię Kanaanu, Jahwe zaspokoi wszystkie potrzeby egzystencjalne swego ludu (por. 13,5).

Ozeaszowa koncepcja exodusu zakłada wreszcie jego typologiczny wa$l^{35}$. Prorok wykorzystuje fundamentalne dla historii i tożsamości Izraela wydarzenie Wyjścia (typ) dla opisania ponownego wybrania i wybawienia ludu (antytyp). Ten schemat typologiczny jest wyraźnie obecny w 2,16-17 i 12,10. Zauważa się go również w 8,13; 9,3 i 11,56 , gdzie pojawia się zapowiedź powrotu Izraela do Egiptu, co stanowić ma karę za popełnione grzechy. Yair Hoffman klucz do Ozeaszowej typologii exodusu widzi w rozdz. 2. W tym tekście odnowienie przymierza $(2,20)$ jest możliwe, gdy dokona się ponowny exodus, a jeszcze wcześniej będzie miała miejsce nowa niewola egipska ${ }^{37}$. Ta opinii wymaga jednak pewnej korekty. Po pierwsze, Ozeasz nie mówi o „nowym” exodusie, raczej postrzega historyczny exodus jako archetyp wszelkiego działania zbawczego Boga (por. formułę autoprezentacji Jahwe w 13,4, która przechodzi w wyznanie, że „poza Nim nie ma żadnego zbawcy”). Po drugie, zamiast mówić o „nowym” exodusie, Ozeasz zapowiada powrót do historycznego Wyjścia z ziemi egipskiej. Nie chodzi zatem o jakieś nowe działanie zbawcze Boga, ale o powrót do idealnych początków Izraela. Po trzecie, typologia stosowana przez Ozeasz prowadzi do idealizacji historycznego Wyjścia, czego wyrazem jest nie tylko przemilczenie jakichkolwiek epizodów buntu na pustyni. Tę idealizację exodusu dostrzega się jeszcze bardziej w przedstawianiu go jako relacji oblubieńczej między Jahwe i Izraelem, który pozostaje wierny wobec Bożej miłości.

Konkludując Ozeaszową wizję exodusu, należy stwierdzić, że prorok przejął tradycję istniejącą w Królestwie Północnym, eksponując w niej kilka elementów fundamentalnych dla tożsamości Izraela. Podstawą wybrania Izraela jest exodus jako wydarzenie, przez które Bóg objawił swoją miłość wobec niego jako swego syna i jak swojej oblubienicy. Dzięki odniesieniu do exodusu metafory małżeńskiej i rodzicielskiej Ozeasz ukazuje pełną intymności, namiętności i zaangażowania miłość Boga do swego ludu. Idealizacja historii Wyjścia wynika przede wszystkim z pominięcia w niej jakichkolwiek odniesień do buntu czy nieposłuszeństwa Izraela podczas exodusu. W rezultacie zapowiadane typolo-

35 Ten aspekt Ozeaszowego ujęcia exodusu podkreślają przede wszystkim: Y. Hoffman, A North Israelite, s. 120.

36 Początek Oz 11,5 w TM brzmi: „nie wróci do ziemi egipskiej”. Biorąc pod uwagę wcześniejsze zapowiedzi powrotu Izraela do Egiptu, komentatorzy albo idą za $L X X$ i korygują negację $1 \bar{o}^{\supset}$ na $l \hat{o}$, łącząc ten sufiksowany zaimek z końcówką w. 4 („pochyliłem się nad nim i nakarmiłem [go]) (np. W. Rudolph, Hosea, 210; H.W. Wolff, Hosea, 191-192;

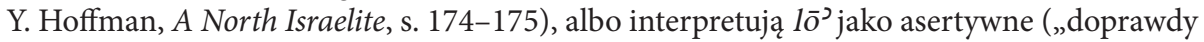
powróci”) (np. F.I. Andersen - D.N. Freedman, Hosea, 584).

37 Y. Hoffman, A North Israelite, s. 171, 175. 
gicznie przez proroka przyszłe wybawienie Izraela jawi się jako powrót do idealnej relacji między Jahwe i Izraelem mającej charakteryzować wyjście z Egiptu.

\section{Bibliografia}

Alonso Schökel, L., Salvezza e liberazione: l'Esodo (Epifania della Parola 8), Bologna 1997.

Andersen, F.I. - Freedman, D.N., Hosea. A New Translation with Introduction and Commentary (AB 24), New York et al. 1980.

Andersen, F.I. - Freedman, D.N., Amos. A New Translation with Introduction and Commentary (AB 24A), New York et al. 1989.

Corrêa Lima, M.L., „Os 9,10-17 nella dinamica del messaggio del Libro di Osea”, w: E.M. Obara - G.P.D. Succu (red.), Uomini e profeti. Scritti in onore do Horacio Simian-Yofre SJ (AnBib 202), Roma 2013, 157-193.

Dearman, J.A., The Book of Hosea (NICOT), Grand Rapids - Cambridge 2010.

Fishbane, M., Biblical Interpretation in Ancient Israel, Oxford 1988.

Hoffman, Y., „A North Israelite Typological Myth and a Judean Historical Tradition. The Exodus in Hosea and Amos", VT 39 (1989) 169-182.

Holt, E.K., Prophesy in the Past. The Use of Israel's History in the Book of Hosea (JSOT.S 194), Sheffield 1995.

Jeremias, J., Der Prophet Amos (ATD 24.2), Göttingen 1995.

Joüon, P. - Muraoka, T., A Grammar of Biblical Hebrew (Subsidia Biblica 27), Roma 2006.

Macintosh, A.A., A Critical and Exegetical Commentary on Hosea (ICC), Edinburgh 1997.

Mays, J.L., Amos. A Commentary (OTL), Philadelphia 1969.

Paul, S.M., Amos. A Commentary on the Book of Amos (Hermeneia) Minneapolis 1991.

Rudolph, W., Joel - Amos - Obadja - Jona (KAT 13.2), Gütersloh 1971.

Schmidt, W.H., „Die deuteronomistische Redaktion des Amosbuches”, ZAW 77 (1965) 168-193.

Sweeney, M.A., The Twelve Prophets, I (Berit Olam), Collegeville 2000.

Weinfeld, M., Deuteronomy 1-11. A New Translation with Introduction and Commentary (AB 5), New York et al. 1991.

Wolff, H.W., Hosea. A Commentary on the Book of the Prophet Hosea (Hermeneia), Philadelphia 1974.

Wolff, H.W., Joel and Amos. A Commentary on the Books of Prophets Joel and Amos (Hermeneia), Philadelphia 1977.

Zimmerli, W. „Io sono Jahvé”, w: Rivalazione di Dio. Una teologia dell'Antico Testamento (Milano 1975), 18-44.

Zimmerli, W., „Un genere profetico: il detto dell'autodimostrazione divina (detto di dimostrazione)", w: Rivelazione di Dio. Una teologia dell'Antico Testamento (Milano 1975), 109-119. 